DOI: http://dx.doi.org/10.15517/rce.v34i2.27330

\title{
BETTER OFF WITHOUT THE EURO? EVALUATING MONETARY POLICY AND MACROECONOMIC PERFORMANCE FOR THE U.K. AND SWEDEN
}

\author{
Stefan Krause Montalbert ${ }^{1}$
}

\begin{abstract}
I compare macroeconomic performance, measured by the volatility of real GDP and inflation, for two of the countries that opted not to enter the EMU: the United Kingdom and Sweden. In particular, I am interested in finding out how much of the macroeconomic performance changes experienced by the U.K. and Sweden after 1999 is due to increased efficiency in the conduct of independent monetary policy. Eventually, the objective is to analyze whether or not further changes in macroeconomic volatility could have been attained if these two countries would have instead adopted the Euro starting January 1999.
\end{abstract}

KEYWORDS: EURO AREA; MONETARY POLICY; INFLATION AND OUTPUT VOLATILITY.

\section{RESUMEN}

En este artículo comparo los resultados macroeconómicos, medidos por la volatilidad del PIB real y la inflación, para dos de los países que optaron por no entrar en la UEM: el Reino Unido y Suecia. En particular, estoy interesado en saber cuánto de los cambios en el desempeño macroeconómicos experimentados por el Reino Unido y Suecia después de 1999 se debe al aumento de la eficiencia en la conducción de la política monetaria independiente. El objetivo es analizar los cambios en la volatilidad macroeconómica que se podrían haber alcanzado si estos dos países hubieran adoptado el Euro a partir de enero de 1999.

PALABRAS CLAVE: EUROZONA, POLÍTICA MONETARIA, VOLATILIDAD DE LA INFLACIÓN Y DEL PRODUCTO. 


\section{INTRODUCTION}

In this paper, I compare macroeconomic performance, measured by the volatility of real GDP and inflation, for two of the countries that opted out of joining the European Economic and Monetary Union (EMU) in 1999: the United Kingdom and Sweden. In particular, I am interested in finding out how much of the macroeconomic performance changes experienced by the U.K. and Sweden after 1999 is due to increased efficiency in the conduct of independent monetary policy, as opposed to changes in the impact of demand and supply disturbances. Eventually, the objective is to analyze whether or not further changes in macroeconomic volatility could have been observed if these two countries would have instead adopted the Euro starting January 1999.

The study's objective is to shed some additional light on analyzing the pros and cons of EMU membership; while revisiting some past (albeit once again relevant) questions, including:

- Are changes in fluctuations due to policy, shocks, structural changes, or other factors (Ahmed, Levin, \& Wilson, 2002; Dynan, Elmendorf, \& Sichel, 2006; Herrera \& Pesavento, 2005; McConnell \& Perez-Quiros, 2000; Stock \& Watson, 2002, 2003)?

- $\quad$ Are Inflation Targeting (Sweden and the UK), and price stability as the main mandate (EMU) still the best policies for minimizing fluctuations (Bernanke, Laubach, Mishkin, \& Posen, 1999; Krause \& Méndez, 2008; Mishkin \& Schmidt-Hebbel, 2002; Rudebusch \& Svensson, 1999, 2000; Walsh, 1995)?

- $\quad$ Do Sweden and the UK have anything to gain at all if they were to join the EMU (Alesina \& Barro, 2002; Pesaran, Smith, \& Smith, 2005; Rose \& Engel, 2002; Söderström, 2008)?

Figures 1.1 and 1.2 document the changes in macroeconomic volatility that the U.K. and Sweden have experienced between the pre- and the post-Euro periods, the latter of which is again divided into the subperiods before and after Lehman Brothers' filing for Chapter 11 bankruptcy on September 2008, and the ensuing financial crisis and worldwide recession. For comparison purposes, I also include the data for the Euro Area as a whole; using a weighted average for the period comprising 1991 and 1998. Given the quarterly data availability, I will focus on the following three subperiods throughout the paper:

- $\quad$ Period 1: 1991:QI-1998:QIV

- Period 2: 1999:QI-2008:QII

- Period 3: 2008:QIII-2010:QIV

The top part of Figure 1.1 reports the standard deviation of the real GDP output gap (measured as deviations from an HP-trend with a parameter of 1600); while the bottom part reports the standard deviation from the actual growth rate data series. For the U.K., real volatility either remained unchanged or slightly increased when comparing the 1991:QI-1998:QIV and the 1999:QI-2008:QII periods, depending on whether I consider the volatility of the output gap or of GDP growth, respectively. In the case of Sweden, both measures of real volatility suggest a decline between Period 1 and Period 2. Finally, both countries experienced a substantially larger variance after 2008:QIII, when compared to either of the two prior periods. 


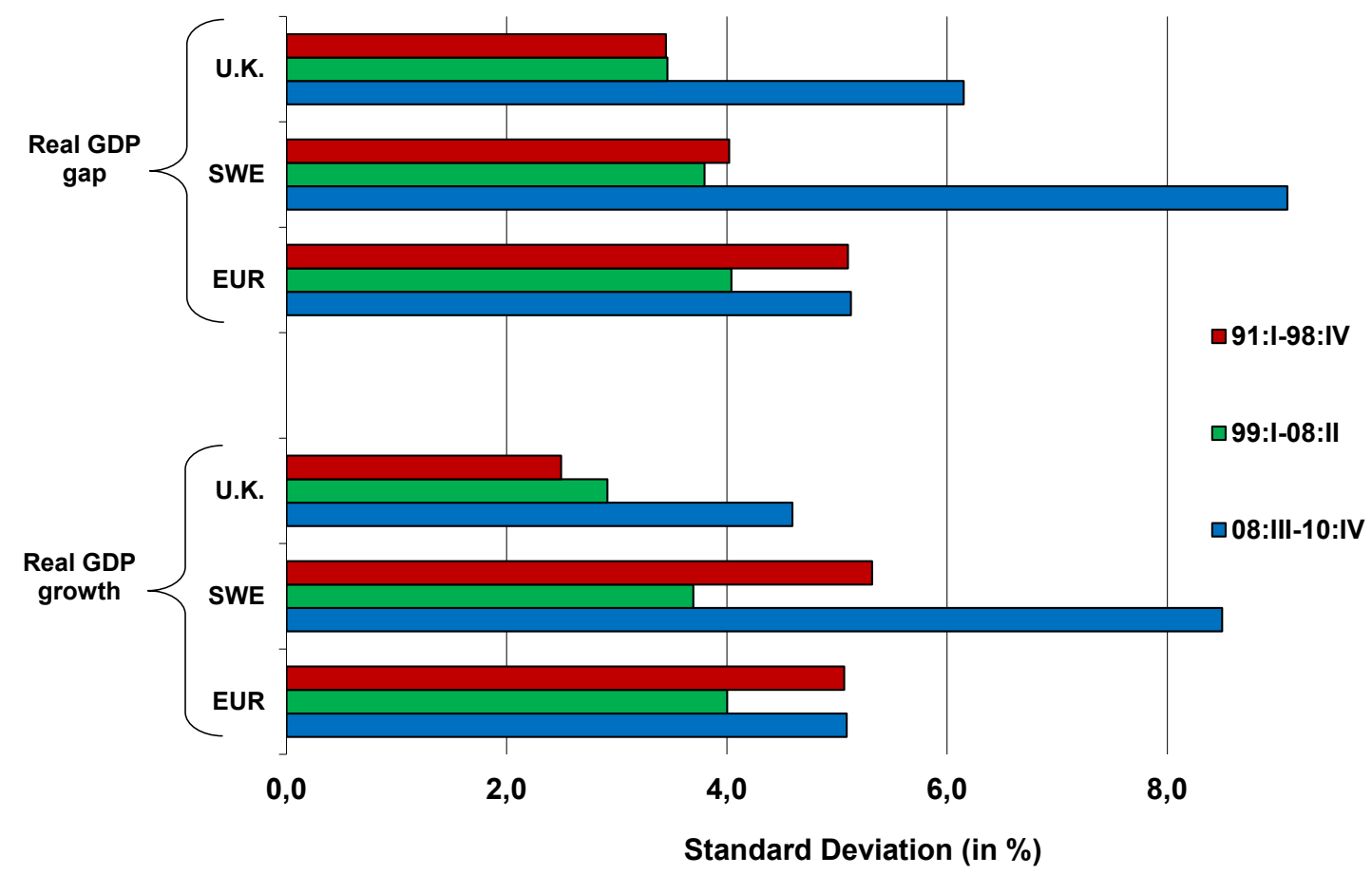

Source: Own elaboration based on data from Datastream.

Figure 1.2 shows how the standard deviation of inflation has changed between the three periods, with the top part reporting the volatility measure centering average inflation at a $2 \%$ level for all 3 periods, and the bottom part reporting it using each period's average inflation as the center point. Given the relatively low levels of inflation prevalent for both countries since the beginning of the 1990s, the magnitudes of the standard deviations are very similar. The general observation is that for Sweden and the U.K., inflation volatility fell by about 30\%-35\% when comparing Period 1 and Period 2, and then in Period 3 it returned to near its value of Period 1. 
FIGURE 1.2

CHANGES IN INFLATION VOLATILITY

(1991:I-1998 IV / 1999:I-2008:II / 2008:III-2010:IV)

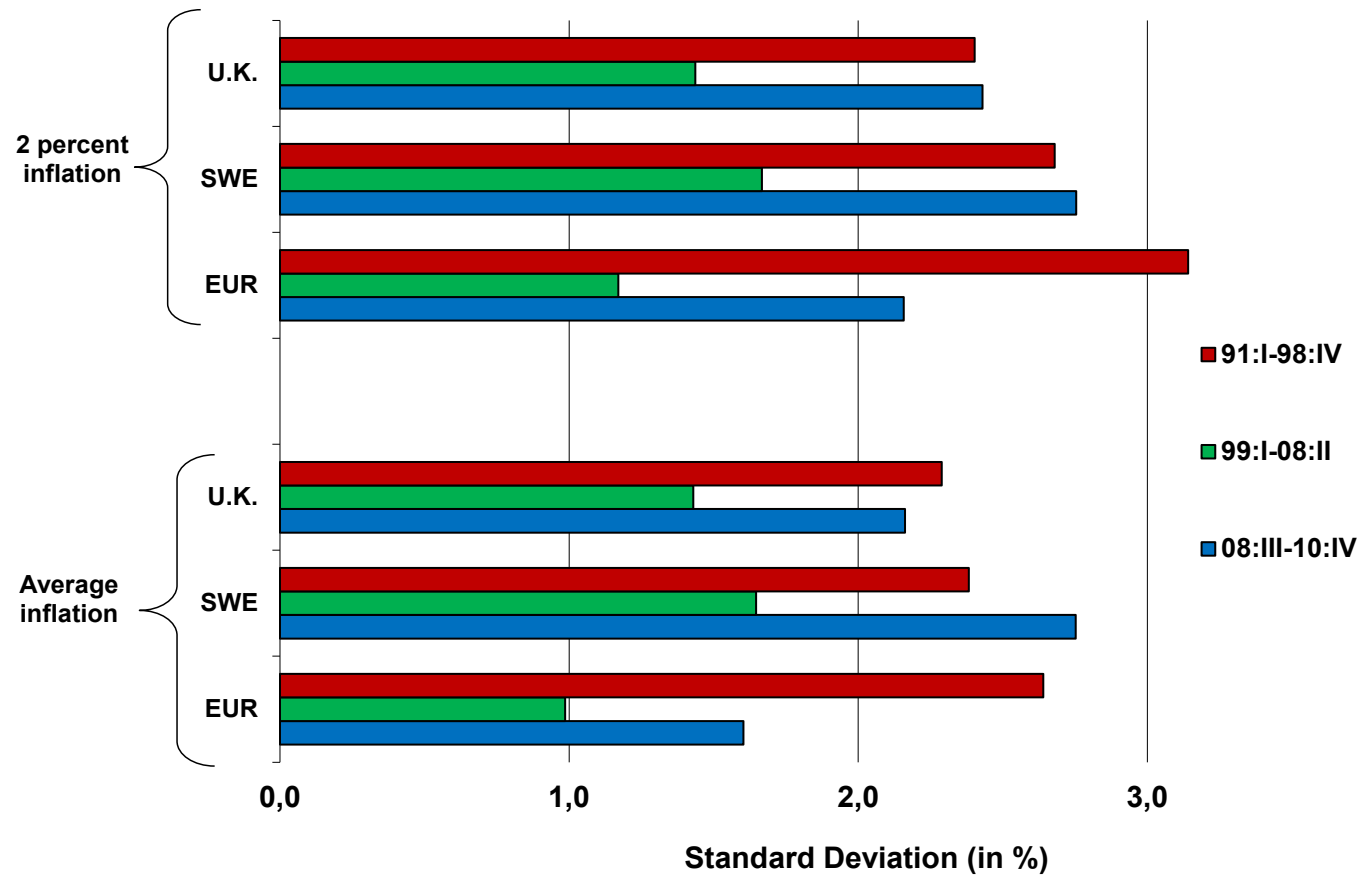

Source: Own elaboration based on data from Datastream.

The above figures serve not only to show the actual changes in macroeconomic performance that both countries experienced over the past 20 years, but it also helps to illustrate that the measured changes in the volatility of both inflation and real output do not change perceptibly with a different choice of center points or targets. I shall return to this last point later in the paper.

The remainder of the paper is organized as follows. Section II details the set-up and estimation of an aggregate demand - aggregate supply (AD-AS) model, that will later be employed to assess the role monetary policy has played in the observed changes in macroeconomic performance in Section III. It also lays out the groundwork for the counter-factual analysis used to gauge macroeconomic performance under the Euro. Finally, Section IV presents some concluding remarks. 


\title{
II. METHODOLOGY
}

\author{
ESTIMATING THE AD-AS MODEL
}

Estimating the dynamics of the output gap and inflation plays a dual role in assisting us to perform the task at hand: First, the estimated coefficients are used to derive the Taylor (1979) frontier for each country and each subperiod; this efficiency frontier is the main identification tool I employ to determine how much of the observed changes in macroeconomic performance are due to monetary policy, as in Cecchetti, Flores-Lagunes, and Krause (2006). I describe this in more detail on Section III. Second, the specification will serve to perform the counter-factual analysis, and generate alternative scenarios for the dynamic behavior of real GDP and inflation under the adoption of the Euro, as explained on Section IV.

The AD-AS model should be general enough for the countries of interest, to allow for direct comparisons; and meet all model specification criteria. With this in mind, I estimate the following specification:

$$
\begin{gathered}
y_{t}=\alpha_{10}+\sum_{l=1}^{2} \alpha_{1 l} y_{t-l}+\phi\left(\iota_{t-1}-\pi_{t-1}\right)+\psi_{y} \pi_{t-1}^{x}+u_{y t}, \\
\pi_{t}=\alpha_{20}+\sum_{l=1}^{4} \alpha_{2 l} \pi_{t-l}+\sum_{l=1}^{2} \gamma_{l} y_{t-l}+\psi_{\pi} \pi_{t-1}^{x}+u_{\pi t} .
\end{gathered}
$$

This formulation is based on the empirical observation that monetary policy actions affect output before inflation (see, for instance, the theoretical model of Svensson, 1997; and the empirical model in Rudebusch and Svensson, 1999; among others). The error terms assumed to be uncorrelated, and to have zero mean and constant variance.

The first equation represents an aggregate demand or IS curve. It relates the output gap y to two of its own lags to account for the persistent nature of real GDP2; and one lag of the real interest rate $i-\pi$, which captures the effect of intertemporal substitution in consumption (Clarida, Galí, \& Gertler, 1999, 2000). The second equation is an aggregate supply or Phillips curve. Here, inflation is assumed to be a function of four of its own lags, and two lags of the output gap accounting for the pressure of increased economic activity on prices.

When dealing with open economies, it's important to gauge the effect of external shocks. The option employed in this study is to augment both equations with Euro Area inflation translated into domestic currency $\pi^{\mathrm{x}}$ (lagged one period). This is done to take into consideration the inter-relation between the economy of interest and that of Euro Area ${ }^{3}$.

I estimate equations (1) and (2) for each country separately via OLS for the pre- and post-Euro years, using quarterly data taken from Datastream ${ }^{4}$.

The lags of output were chosen based on goodness of fit criteria.

We compute external inflation $\varpi^{\wedge} \mathrm{x}$ as the sum of the devaluation rate of the local currency with respect to the Euro, and the inflation in the Euro Area. The data sources are as follows: SW KRONA TO EURO (SD); EURO TO UK £ (ECU HISTORY WMR); SW GDP (CVM) CONA; UK GDP (CVM) CONA; EURO HICP; SW CPI NADJ; UK CPI NADJ; EURO OVERNIGHT INDEX AVERAGE(EONIA); SWEDEN INTERBANK T/N - MIDDLE RATE; UK INTERBANK OVERNIGHT - MIDDLE RATE 
TABLE 1.1

OUTPUT GAP EQUATION FOR THE U.K. AND SWEDEN

\begin{tabular}{|c|c|c|c|c|}
\hline & \multicolumn{2}{|c|}{ United Kingdom } & \multicolumn{2}{|c|}{ Sweden } \\
\hline $\begin{array}{l}\text { Dep. Variable: Quarterly real } \\
\text { GDP Gap } \\
\text { (annualized, in \%) }\end{array}$ & $\begin{array}{l}\text { 1990:QI- } \\
\text { 1998:QIV }\end{array}$ & $\begin{array}{l}\text { 1999:QI- } \\
\text { 2010:QIV }\end{array}$ & $\begin{array}{l}\text { 1990:QI- } \\
\text { 1998:QIV }\end{array}$ & $\begin{array}{l}\text { 1999:QI- } \\
\text { 2010:QIV }\end{array}$ \\
\hline Real GDP Gap (t-1) & $\begin{array}{c}0.768 \\
(0.00)\end{array}$ & $\begin{array}{c}0.783 \\
(0.00)\end{array}$ & $\begin{array}{c}0.602 \\
(0.00)\end{array}$ & $\begin{array}{c}0.763 \\
(0.00)\end{array}$ \\
\hline Real GDP Gap (t-2) & $\begin{array}{l}-0.019 \\
(0.90)\end{array}$ & $\begin{array}{r}0.032 \\
(0.86)\end{array}$ & $\begin{array}{l}0.105 \\
(0.53)\end{array}$ & $\begin{array}{l}-0.029 \\
(0.85)\end{array}$ \\
\hline Real Interest Rate (t-1) & $\begin{array}{l}-0.127 \\
(0.00)\end{array}$ & $\begin{array}{l}-0.171 \\
(0.07)\end{array}$ & $\begin{array}{l}-0.047 \\
(0.17)\end{array}$ & $\begin{array}{l}-0.556 \\
(0.00)\end{array}$ \\
\hline $\begin{array}{l}\text { Euro Area Inflation in Local } \\
\text { Currency (t-1) }\end{array}$ & $\begin{array}{l}-0.006 \\
(0.15)\end{array}$ & $\begin{array}{l}-0.014 \\
(0.05)\end{array}$ & $\begin{array}{l}-0.007 \\
(0.10)\end{array}$ & $\begin{array}{l}-0.024 \\
(0.07)\end{array}$ \\
\hline 2008:QIII - 2010:QIV & & $\begin{array}{l}-1.502 \\
(0.06)\end{array}$ & & $\begin{array}{l}-1.560 \\
(0.02)\end{array}$ \\
\hline R-squared & 0.80 & 0.77 & 0.60 & 0.86 \\
\hline $\begin{array}{l}\text { Durbin alt. } F \text {-test for auto- } \\
\text { correlation }\end{array}$ & $\begin{array}{c}0.15 \\
(0.71)\end{array}$ & $\begin{array}{c}0.70 \\
(0.41)\end{array}$ & $\begin{array}{c}6.20 \\
(0.02)\end{array}$ & $\begin{array}{c}0.89 \\
(0.35)\end{array}$ \\
\hline LM Chi-test for ARCH & $\begin{array}{c}0.02 \\
(0.89)\end{array}$ & $\begin{array}{c}0.13 \\
(0.72)\end{array}$ & $\begin{array}{c}0.88 \\
(0.35)\end{array}$ & $\begin{array}{c}0.66 \\
(0.42)\end{array}$ \\
\hline $\begin{array}{l}\text { Augmented DF } Z \text {-test for } \\
\text { unit root of residuals }\end{array}$ & $\begin{array}{l}-5.76 \\
(0.00)\end{array}$ & $\begin{array}{l}-7.06 \\
(0.00)\end{array}$ & $\begin{array}{l}-6.28 \\
(0.00)\end{array}$ & $\begin{array}{l}-7.14 \\
(0.00)\end{array}$ \\
\hline No. of observations & 34 & 48 & 34 & 48 \\
\hline
\end{tabular}

Source: Own elaboration based on data from Datastream.

Note: P-values obtained from white-corrected, robust standard errors are in parenthesis. 
TABLE 1.2

INFLATION EQUATION FOR THE U.K. AND SWEDEN

\begin{tabular}{|c|c|c|c|c|}
\hline & \multicolumn{2}{|c|}{ United Kingdom } & \multicolumn{2}{|c|}{ Sweden } \\
\hline $\begin{array}{l}\text { Dep. Variable: Quarterly } \\
\text { inflation } \\
\text { (annualized, in \%) }\end{array}$ & $\begin{array}{l}\text { 1990:QI- } \\
\text { 1998:QIV }\end{array}$ & $\begin{array}{l}\text { 1999:QI- } \\
\text { 2010:QIV }\end{array}$ & $\begin{array}{l}\text { 1990:QI- } \\
\text { 1998:QIV }\end{array}$ & $\begin{array}{l}\text { 1999:QI- } \\
\text { 2010:QIV }\end{array}$ \\
\hline Inflation (t-1) & $\begin{array}{l}-0.039 \\
(0.87)\end{array}$ & $\begin{array}{c}0.362 \\
(0.12)\end{array}$ & $\begin{array}{r}0.320 \\
(0.23)\end{array}$ & $\begin{array}{l}0.296 \\
(0.16)\end{array}$ \\
\hline Inflation (t-2) & $\begin{array}{l}0.268 \\
(0.06)\end{array}$ & $\begin{array}{l}-0.171 \\
(0.43)\end{array}$ & $\begin{array}{c}0.218 \\
(0.29)\end{array}$ & $\begin{array}{l}-0.152 \\
(0.30)\end{array}$ \\
\hline Inflation (t-3) & $\begin{array}{r}0.240 \\
(0.35)\end{array}$ & $\begin{array}{l}-0.042 \\
(0.87)\end{array}$ & $\begin{array}{c}0.231 \\
(0.23)\end{array}$ & $\begin{array}{c}0.180 \\
(0.14)\end{array}$ \\
\hline Inflation (t-4) & $\begin{array}{r}0.211 \\
(0.47)\end{array}$ & $\begin{array}{l}-0.069 \\
(0.78)\end{array}$ & $\begin{array}{l}-0.385 \\
(0.12)\end{array}$ & $\begin{array}{l}-0.175 \\
(0.27)\end{array}$ \\
\hline Real GDP Gap (t-1) & $\begin{array}{r}0.692 \\
(0.30)\end{array}$ & $\begin{array}{c}0.374 \\
(0.15)\end{array}$ & $\begin{array}{c}0.048 \\
(0.91)\end{array}$ & $\begin{array}{c}0.244 \\
(0.28)\end{array}$ \\
\hline Real GDP Gap (t-2) & $\begin{array}{r}0.267 \\
(0.67)\end{array}$ & $\begin{array}{l}-0.321 \\
(0.12)\end{array}$ & $\begin{array}{l}-0.029 \\
(0.95)\end{array}$ & $\begin{array}{l}-0.184 \\
(0.28)\end{array}$ \\
\hline $\begin{array}{l}\text { Euro Area Inflation in Local } \\
\text { Currency }(\mathrm{t}-1)\end{array}$ & $\begin{array}{l}0.015 \\
(0.46)\end{array}$ & $\begin{array}{r}-0.002 \\
(0.89)\end{array}$ & $\begin{array}{l}-0.003 \\
(0.85)\end{array}$ & $\begin{array}{l}-0.010 \\
(0.56)\end{array}$ \\
\hline 2008:QIII - 2010:QIV & & $\begin{array}{l}1.491 \\
(0.08)\end{array}$ & & $\begin{array}{l}-0.256 \\
(0.82)\end{array}$ \\
\hline R-squared & 0.53 & 0.27 & 0.40 & 0.18 \\
\hline $\begin{array}{l}\text { Durbin alt. } F \text {-test for auto- } \\
\text { correlation }\end{array}$ & $\begin{array}{l}6.06 \\
(0.02)\end{array}$ & $\begin{array}{c}0.01 \\
(0.93)\end{array}$ & $\begin{array}{c}1.92 \\
(0.18)\end{array}$ & $\begin{array}{c}0.70 \\
(0.41)\end{array}$ \\
\hline LM Chi-test for ARCH & $\begin{array}{c}0.00 \\
(0.96)\end{array}$ & $\begin{array}{l}5.10 \\
(0.02)\end{array}$ & $\begin{array}{c}3.68 \\
(0.06)\end{array}$ & $\begin{array}{c}1.37 \\
(0.24)\end{array}$ \\
\hline $\begin{array}{l}\text { Augmented DF } Z \text {-test for } \\
\text { unit root of residuals }\end{array}$ & $\begin{array}{l}-5.57 \\
(0.00)\end{array}$ & $\begin{array}{l}-6.49 \\
(0.00)\end{array}$ & $\begin{array}{l}-4.32 \\
(0.00)\end{array}$ & $\begin{array}{l}-6.82 \\
(0.00)\end{array}$ \\
\hline No. of observations & 32 & 48 & 32 & 48 \\
\hline
\end{tabular}

Source: Own elaboration based on data from Datastream.

Note: P-values obtained from white-corrected, robust standard errors are in parenthesis. 
Table 1.1 reports the estimates of the output gap equation (1) for the U.K. and Sweden for two subperiods. Period 1 as defined on Section I, includes the pre-Euro years (1990:QI-1998:QIV). Given the relatively small size of Period 3 (10 quarters), I estimate equation (1) for the entire post-Euro period (1999:QI-2010:QIV), adding a dummy variable that takes the value of 1 on and after 2008:QIII.

The estimates from the output gap equation confirm that real GDP is highly persistent for both countries and subperiods, and that increases in the one-period lagged real interest rate are associated with a reduction in aggregate economic activity, as predicted.

As for the other variables, Euro Area Inflation in Local Currency has a negative, and almost always significant effect on the output gap; meanwhile, as expected, real GDP gap is significantly lower on average after 2008:QIII, as a result of the Great Recession.

Turning to the inflation equation (2), the effect of lagged values of inflation and the output gap vary depending on the country and the period, as reported in Table 1.2. In general, coefficients have the expected sign, but are in many cases insignificant.

Euro Area Inflation in Local Currency does not enter any of the regressions with a significant sign, whereas in Period 3 inflation becomes significantly higher for the U.K., but not so for the case of Sweden.

It is important to note that the general model specification employed fits the data relatively well - mainly in explaining the dynamics of the output gap. R-squared statistics range between 0.60 and 0.86 for the estimation of equation (1). For equation (2), the R-squared ranges between 0.18 and 0.53 . In the Appendix I discuss some further diagnostics tests. 


\section{RESULTS}

\section{ESTIMATING THE EFFICIENCY FRONTIER}

The employment of the inflation-output tradeoff is in the spirit of Fuhrer (1997), Cover and Pecorino (2005), McMillin and Fackler (2006). Following Taylor (1979), an efficiency frontier can be derived by minimizing a central bank's objective function, subject to the constraints imposed by the dynamic structure of the economy in equations (1) and (2). The derivation of the frontier I employ for the analysis employs the method from Chow (1975), and is based on a similar specification by Cecchetti et al. (2006); therefore, I will only briefly describe it and modify it accordingly to account for the structural model estimated above.

Let's begin by expressing the model in equations (1)-(2) using its state-space representation:

$$
\begin{gathered}
Y_{t}=A+B Y_{t-1}+C i_{t-1}+D X_{t}+v_{t} \\
\text { with: } Y_{t}=\left[\begin{array}{c}
y_{t} \\
y_{t-1} \\
\pi_{t} \\
\pi_{t}-1 \\
\pi_{t-2} \\
\pi_{t-3}
\end{array}\right] ; A=\left[\begin{array}{c}
\alpha_{10} \\
0 \\
\alpha_{20} \\
0 \\
0 \\
0
\end{array}\right] ; B=\left[\begin{array}{cccccc}
\alpha_{11} & \alpha_{12} & -\phi & 0 & 0 & 0 \\
1 & 0 & 0 & 0 & 0 & 0 \\
\gamma_{1} & \gamma_{2} & \alpha_{21} & \alpha_{22} & \alpha_{23} & \alpha_{24} \\
0 & 0 & 1 & 0 & 0 & 0 \\
0 & 0 & 0 & 1 & 0 & 0 \\
0 & 0 & 0 & 0 & 1 & 0
\end{array}\right] ; \\
c=\left[\begin{array}{c}
\phi \\
0 \\
0 \\
0 \\
0 \\
0
\end{array}\right] ; D=\left[\begin{array}{cc}
\Psi_{1} & \theta_{1} \\
0 & 0 \\
\Psi_{2} \theta_{2} \\
0 & 0 \\
0 & 0 \\
0 & 0
\end{array}\right] ; X_{t}=\left[\begin{array}{c}
e_{t-1}+\pi_{t-1}^{x} \\
\text { Period3 }
\end{array}\right] ; v_{t}=\left[\begin{array}{c}
u_{y t} \\
0 \\
u_{\pi t} \\
0 \\
0 \\
0
\end{array}\right] ;
\end{gathered}
$$

where all variables are as described in Section II; while Period3 takes a value of 1 between 2008:III and 2010:IV, and 0 otherwise.

The policymaker's problem is to choose a path for the interest rate, in order to minimize the following loss function:

$$
L=\lambda \operatorname{var}\left(\pi_{t}\right)+(1-\lambda) \operatorname{var}\left(y_{t}\right)
$$

subject to the constraints imposed by equation (3), where $\lambda$, which can take a value between 0 and 1 , represents the relative weight the policymaker places on stabilizing inflation. The solution for the interest rate can be written as:

$$
i_{t}=\Gamma Y_{t}+\Psi X_{t}
$$


where $\Gamma$ is the vector of reaction coefficients of the policy instrument to changes in inflation and the output gap, and $\Psi$ is a constant term which depends on $B, c$, and $D$. The control problem is solved by finding $\Gamma$ such that: ${ }^{5}$

$$
\Gamma=-\left(c^{\prime} H c\right)^{-1} c^{\prime} H B
$$

and

$$
H=\Lambda+(B+c \Gamma)^{\prime} H(B+c \Gamma)
$$

where $\Lambda$ is a $6 \times 6$ matrix containing the relative weights given to the variabilities of the output gap and inflation on the first and third diagonal elements, respectively; and zeroes elsewhere. The efficiency frontier is then derived by applying this procedure for different values of lambda ranging between 0 and 1 .

\section{GRAPHICAL ANALYSIS}

In a first step I apply the optimal control problem detailed above to estimate the efficiency frontiers. Since these curves represent the best a policymaker can do in the presence of shocks and subject to the dynamic structure of the economy, being at the frontier means that demand shocks have been completely neutralized by way of optimal policy, and all that remains is the trade-off policymakers face in terms of how much supply shocks will affect inflation and the output gap, respectively. Choosing different values of the preference parameter $\lambda$ would be therefore trace this trade-off. The efficiency frontiers also serve as an evaluation tool to assess policy performance - the closer actual macroeconomic performance is to the frontier, the closer policy is to being optimal (Cecchetti et al., 2006).

Given that one minimizes (4), subject to (1)-(2) jointly for Period 2 and Period 3 (as a result of the relatively small size of the latter), the manner in which the frontiers for the pre- and post-crisis periods are constructed is as follows. First, I assume that the general structure of the economy has remained unchanged between 1999:QI and 2010:QIV. Second, the only differences introduced are the (constant) effect of the crisis on the output gap and inflation in Period 3, and the assumption that the shocks to said variables (represented by the residuals $u_{y}$ and $u_{\pi}$, respectively) will be of a different order of magnitude depending on the period. As a result of these two assumptions, the optimal policy rule in (5) will be the same for Period 2 and Period 3, which implies, given the dynamics of inflation and the output gap, that the shape of the efficiency frontiers for both subperiods will be identical. Nevertheless, the relative position of the curves may vary depending on the magnitude of the shocks, since the latter will be different by definition.

Figures 2.1-2.2 present the estimated frontiers for the three periods of interest, 1991:I-1998:IV, 1999:I-2008:II and 2008:III-2010:IV, for the U.K. and Sweden, respectively. In each of these graphs I also include the macroeconomic performance point for each subperiod, which is given by the pair of standard deviations of the real output gap and inflation deviations from a $2 \%$ target. The volatility measure of real economic activity is obtained by applying an H-P filter to the original real GDP series, and then computing the second moment of the resulting output gap. It is worthwhile to note that the results are analogous (up to a re-scaling factor) to the ones obtained when using the standard deviation of the GDP growth rates. Similarly, given the low levels of inflation for the two countries over the entire period, the choice of the central point used to compute the volatility measure of inflation does not significantly affect the results. 
FIGURE 2.1

EFFICIENCY FRONTIERS AND PERFORMANCE POINTS

(U.K.: COMPARISON ACROSS SUBPERIODS)

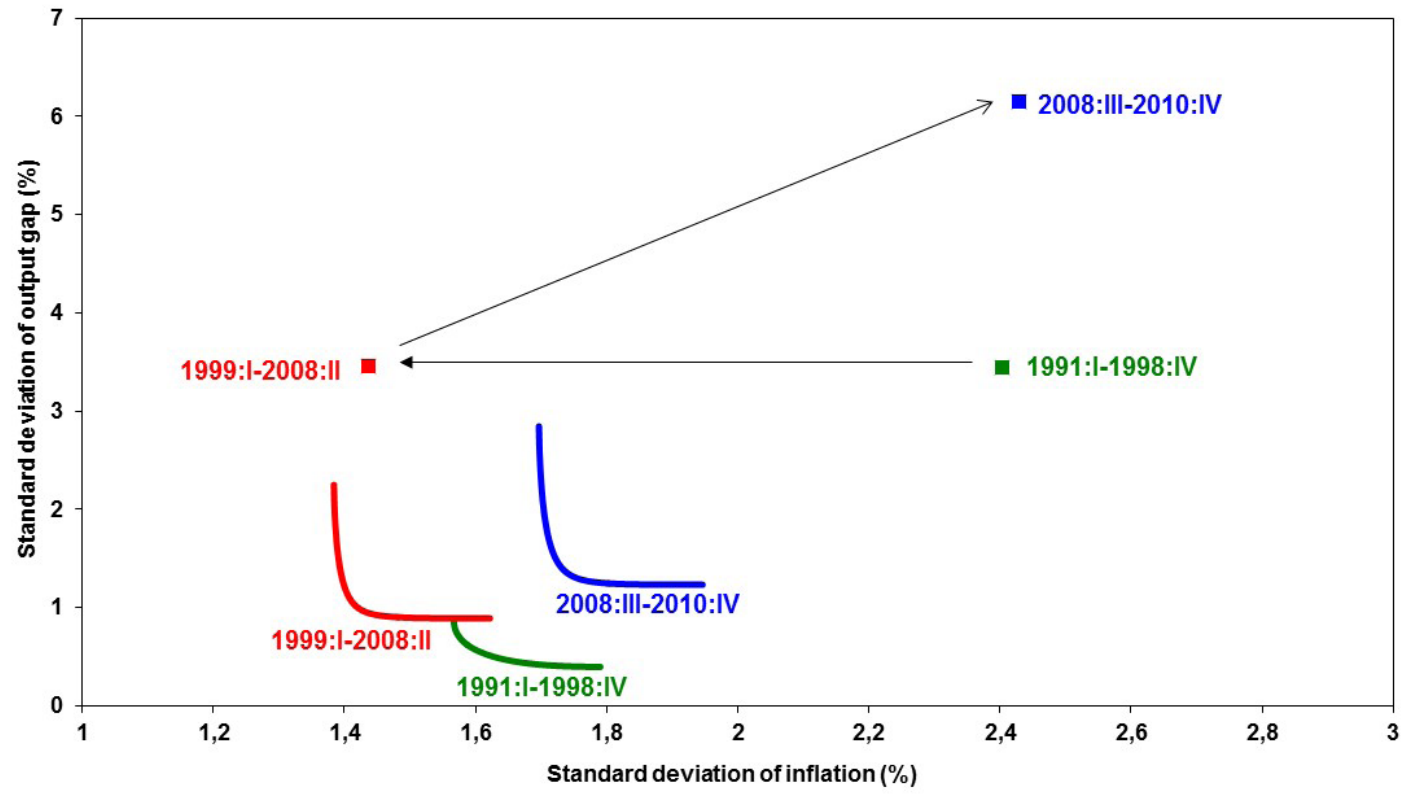

Source: Own elaboration based on data from Datastream.

FIGURE 2.2

EFFICIENCY FRONTIERS AND PERFORMANCE POINTS

(SWEDEN: COMPARISON ACROSS SUBPERIODS)

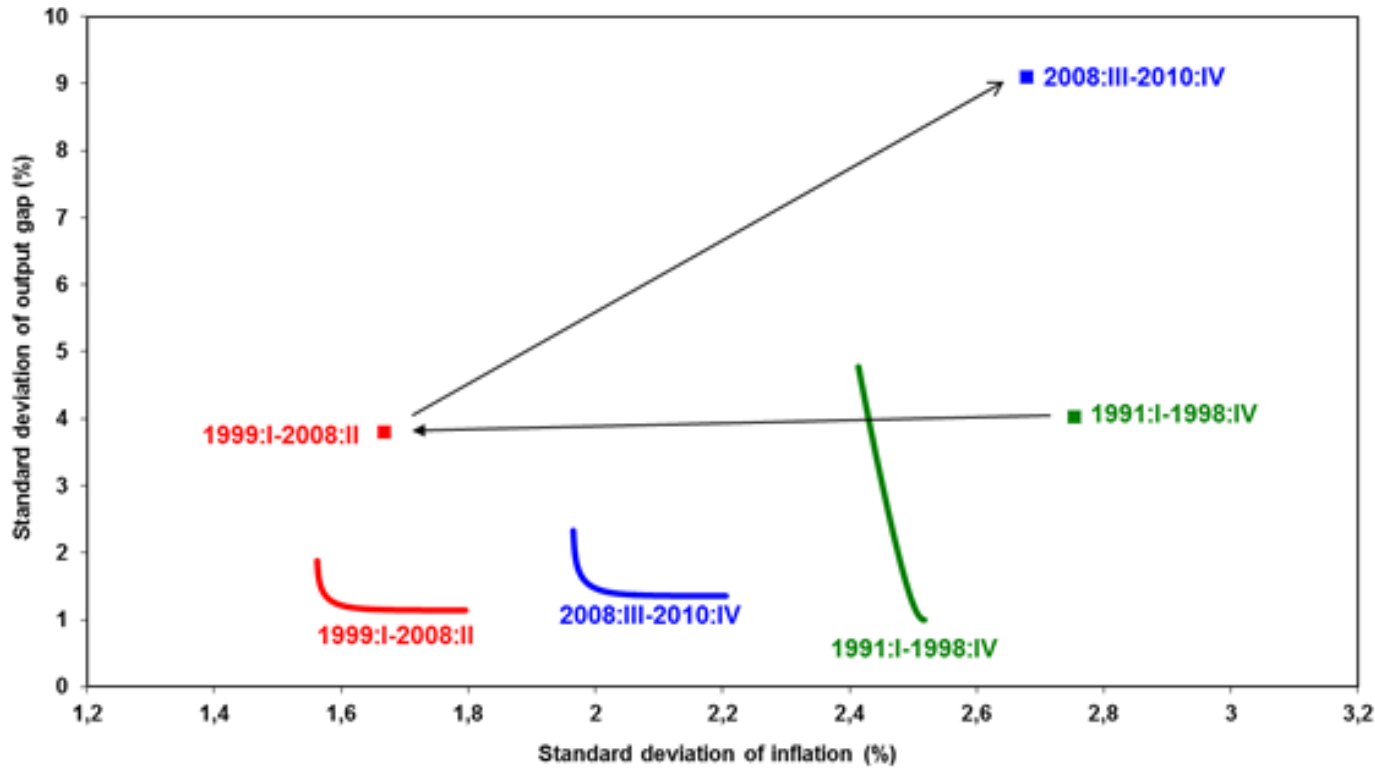

Source: Own elaboration based on data from Datastream. 
The graphical comparison across all three periods leads to some interesting observations. First, since a point moving closer to the origin is associated with both inflation and economic activity having become more stable, there is no ambiguity that both the U.K. and Sweden experienced macroeconomic performances gains between 1991:QI-1998:QIV and 1999:QI-2008:QII: while output volatility remained basically unchanged, inflation volatility decreased for both countries during this time span.

Another observation is that shocks seem to have also been more moderate during Period 2 compared to Period 1 for Sweden, which is represented by an inward shift of the efficiency frontier in Figure 2.2. For the U.K., the graphical analysis does not yield a definite conclusion: the efficiency frontier has moved in a north-west direction, which may simply signify a change in the structure of the economy and the response of output and inflation to supply shocks, without yielding any evidence as to whether the magnitude of said shocks has increased or decreased between Period 1 and Period 2 .

Comparing the pre-crisis and the post-crisis periods one can observe (again, unambiguously) that macroeconomic performance has deteriorated for both countries; not only when looking at the pair of volatilities in Period 3 vis-a-vis Period 2, but also (very evidently in the case of the U.K., while slightly less so for Sweden) when comparing the performance in the post-crisis period to the pre-Euro years.

Finally, shocks in Period 3 have been clearly of larger magnitude than those in Period 2 for both countries. Nevertheless, it is worthwhile to note that, given the relative position of the efficiency frontiers, shocks in the post-crisis years for the case of Sweden appear to be of smaller order than in the pre-Euro stage.

\section{MEASURES OF PERFORMANCE CHANGE AND THE ROLE OF MONETARY POLICY}

In order to address some of the ambiguities left by the graphical analysis above, and also to determine the relative importance monetary policy has played in assisting the observed changes in macroeconomic volatility, I apply the measures of performance and policy efficiency developed by Cecchetti et al (2006) to the current analysis.

The authors employ the loss function in equation (4) to define macroeconomic performance as the actual loss (), which is given by:

$$
P_{i}=\Lambda V\left(\pi_{i}+(1-\lambda) V\left(y_{i}\right), i=1,2,3\right.
$$

where I redefine $\quad V\left(\pi_{i}\right)=E\left(\pi_{i}-\pi^{T}\right)^{2}$ and $V\left(y_{i}\right)=E\left(y_{i}\right)^{2}$ and, with $\pi^{T}$ representing target inflation, and inflation $\pi_{i}$ and the output gap $y_{i}$ as defined above. The index $i=1,2,3$ stands for Period 1 (1991:I-1998:IV), Period 2 (1999:I-2008:II) and Period 3 (2008:III-2010:IV), respectively.

The macro performance change $\Delta P$ can be thusly defined as:

$$
\Delta P_{j+1}^{j}=P_{j}-P_{j+1}, j=1,2
$$

where $\Delta P$ is such that, whenever $\Delta P_{j+1}^{j}>0$, there is a smaller loss (and hence, an improved macroeconomic performance) in Period $j+1$ compared to Period $j$; and conversely.

Analogously, let's define the optimal loss $S$ as:

$$
S_{i}=\lambda V^{*}\left[\pi_{i}(\lambda)\right]+(1-\lambda) V^{*}\left[y_{i}(\lambda)\right], i=1,2,3
$$

where $V^{*}\left[\pi_{i}(\lambda)\right]$ and $V^{*}\left[y_{i}(\lambda)\right]$ are the variabilities of inflation and output under optimal policy for period $l$, respectively. Inese optimal variances are obtained from the values of the volatility pair in the efficiency frontier, linked to the corresponding policy preference parameter $\lambda$. 
Improved policymaking would then be associated with the actual loss $P$ becoming closer to the optimal loss $S$ (graphically, macroeconomic performance getting closer to the efficiency frontier); i.e.,

$$
\Delta E_{j+1}^{j}=\left(P_{j}-S_{j}\right)-\left(P_{j+1}-S_{j+1}\right), j=1,2
$$

where $\Delta E$ is defined such that, if $\Delta E_{j+1}^{j}$, the difference between the actual loss and optimal loss is smaller in Period $j+1$ compared to Period $j$-which would represent improved policymaking.

Finally, the proportion of the macroeconomic performance improvement (or loss, if negative) which can be accounted for by improved policy is given by:

$$
Q_{j}=\frac{\Delta E_{j+1}^{j}}{\left|\Delta P_{j+1}^{j}\right|}
$$

Tables 2.1 and 2.2 report the measures of (and its percentage change, $\frac{\Delta P_{j+1}^{j}}{P_{j}} ; S_{i}$; and $Q$ for the U.K.and Sweden, respectively. In order to examine macroeconomic and policy performance for a broad enough range of policymakers' preferences, I compute the measures using six different values of the parameter $\left(\lambda=\frac{1}{2}, \frac{2}{3}, \frac{4}{5}, \frac{9}{19}, \frac{95}{100}\right.$ and $\left.\frac{99}{100}\right)$ for each of the periods.

For the U.K., Table 2.1 suggests a macroeconomic performance improvement between $16 \%$ and $40 \%$ when comparing Period 1 and Period 2, for the wide range of values for $\lambda$ between 0.5 and 0.99. Since the U.K. (and Sweden, as well) has adopted inflation targeting since October 1992 (January 1993, respectively), it is more likely that the relative weight the policymaker places on stabilizing inflation would be situated in the 0.9-0.99 interval (Krause \& Méndez, 2008). This would place actual performance gain for the U.K. within the narrower 35\%-40\% range. For the U.K., I am able to identify a very substantial role of stabilization policy towards the observed performance improvement between Period 1 and Period 2. While for $\lambda=\frac{2}{3}$ it would explain all of the reduction in macroeconomic volatility, for the more likely range $\lambda^{r} \in[0.9,0.99]$ the contribution of policy would amount to roughly $85 \%$. 
TABLE 2.1

U.K.: MACRO PERFORMANCE CHANGE AND POLICY CONTRIBUTION

\begin{tabular}{|c|c|c|c|c|c|c|c|}
\hline Measure & Period & $\lambda=0.5$ & $\begin{array}{c}\lambda= \\
0.667\end{array}$ & $\lambda=0.8$ & $\lambda=0.9$ & $\begin{array}{l}\lambda= \\
0.95\end{array}$ & $\lambda=0.99$ \\
\hline \multirow{3}{*}{ Actual Loss $\left(\mathrm{P}_{\mathrm{i}}\right)$} & $\begin{array}{c}\text { Period } 1 \\
(90: \text { I-98:IV) }\end{array}$ & 2.925 & 2.751 & 2.612 & 2.507 & 2.455 & 2.413 \\
\hline & $\begin{array}{c}\text { Period } 2 \\
(99: I-08: I I)\end{array}$ & 2.448 & 2.110 & 1.841 & 1.638 & 1.537 & 1.456 \\
\hline & $\begin{array}{c}\text { Period } 3 \\
\text { (08:III-10:IV) }\end{array}$ & 4.290 & 3.668 & 3.174 & 2.802 & 2.615 & 2.467 \\
\hline \multirow{3}{*}{ Optimal Loss $\left(\mathrm{S}_{\mathrm{i}}\right)$} & $\begin{array}{c}\text { Period } 1 \\
(90: \text { I-98:IV) }\end{array}$ & 1.077 & 1.266 & 1.400 & 1.490 & 1.530 & 1.560 \\
\hline & $\begin{array}{l}\text { Period } 2 \\
(99: I-08: I I)\end{array}$ & 1.205 & 1.288 & 1.344 & 1.379 & 1.392 & 1.391 \\
\hline & $\begin{array}{c}\text { Period } 3 \\
\text { (08:III-10:IV) }\end{array}$ & 1.538 & 1.617 & 1.670 & 1.702 & 1.711 & 1.706 \\
\hline \multirow{2}{*}{$\begin{array}{l}\text { Macro performance } \\
\text { change }\left(\Delta \mathrm{P}^{\mathrm{j}}{ }_{\mathrm{j}+1} / \mathrm{P}_{\mathrm{j}}\right)\end{array}$} & $\begin{array}{l}\text { Period } 2- \\
\text { Period } 1\end{array}$ & $16 \%$ & $23 \%$ & $30 \%$ & $35 \%$ & $37 \%$ & $40 \%$ \\
\hline & $\begin{array}{l}\text { Period } 3- \\
\text { Period } 2\end{array}$ & $-75 \%$ & $-74 \%$ & $-72 \%$ & $-71 \%$ & $-70 \%$ & $-69 \%$ \\
\hline \multirow{2}{*}{$\begin{array}{l}\text { Policy contribution } \\
\text { to perf. change } \\
\left(\mathrm{Q}_{\mathrm{j}+\mathrm{j}}^{\mathrm{j}}=\Delta \mathrm{E}_{\mathrm{j}+1}^{\mathrm{j}} /\left|\Delta \mathrm{P}_{\mathrm{j}+1}^{\mathrm{j}}\right|\right)\end{array}$} & $\begin{array}{l}\text { Period } 2- \\
\text { Period } 1\end{array}$ & $127 \%$ & $103 \%$ & $93 \%$ & $87 \%$ & $85 \%$ & $82 \%$ \\
\hline & $\begin{array}{l}\text { Period } 3- \\
\text { Period } 2\end{array}$ & $-82 \%$ & $-79 \%$ & $-76 \%$ & $-72 \%$ & $-70 \%$ & $-69 \%$ \\
\hline
\end{tabular}

Source: Own elaboration based on data from Datastream.

Comparing the pre- and post-crisis subperiods in the U.K. suggests relatively large macro performance losses - in the order of 69\%-75\%. As for the role of policy, this would depend on the chosen value for $\lambda$ : Assuming a preference for inflation stability of 0.9 or larger, policy would be responsible for roughly $70 \%$ of the increased macroeconomic volatility, with larger supply shocks explaining the remaining $30 \%$.

Turning the attention to Sweden on Table 2.2, the measured performance gain between Period 1 and Period 2, would be similar to that of the U.K., ranging between $18 \%$ and $37 \%$ for all reported values of $\lambda$. The more realistic range of $\lambda \in[0.9,0.99]$ would place actual performance gain for Sweden within the narrower $33 \%-37 \%$ range.

Contrary to the U.K., the role of stabilization policy towards the observed performance improvement between Period 1 and Period 2 for Sweden would be quite sensitive to the choice of the policy preference parameter. While for $\lambda=\frac{1}{2}$ it would amount to almost one-half of the macro performance gain, for $\lambda \in[0.9,0.99]$ the contribution of policy would only be about $10 \%-13 \%$. This implies that the diminished effect of supply shocks had, at the very least, roughly equal importance to stabilization policy, and, more likely, played an even more important role in explaining the reduction in macroeconomic fluctuations between 1991:QI-1998:QIV and 1999:QI-2008:QII. 
TABLE 2.2

SWEDEN: MACRO PERFORMANCE CHANGE AND POLICY CONTRIBUTION

\begin{tabular}{|c|c|c|c|c|c|c|c|}
\hline Measure & Period & $\lambda=0.5$ & $\begin{array}{c}\lambda= \\
0.667\end{array}$ & $\lambda=0.8$ & $\lambda=0.9$ & $\begin{array}{l}\lambda= \\
0.95\end{array}$ & $\lambda=0.99$ \\
\hline \multirow{3}{*}{ Actual Loss $\left(\mathrm{P}_{\mathrm{i}}\right)$} & $\begin{array}{l}\text { Period } 1 \\
(90: I-98: I V)\end{array}$ & 3.350 & 3.126 & 2.948 & 2.813 & 2.746 & 2.693 \\
\hline & $\begin{array}{l}\text { Period } 2 \\
(99: I-08: I I)\end{array}$ & 2.732 & 2.376 & 2.093 & 1.880 & 1.774 & 1.688 \\
\hline & $\begin{array}{c}\text { Period } 3 \text { (08:III- } \\
10: \text { IV) }\end{array}$ & 5.923 & 4.864 & 4.022 & 3.388 & 3.071 & 2.818 \\
\hline \multirow{3}{*}{ Optimal Loss $\left(\mathrm{S}_{\mathrm{i}}\right)$} & $\begin{array}{c}\text { Period } 1 \\
(90: I-98: I V)\end{array}$ & 1.759 & 2.013 & 2.215 & 2.368 & 2.441 & 2.438 \\
\hline & $\begin{array}{l}\text { Period } 2 \\
(99: I-08: I I)\end{array}$ & 1.418 & 1.487 & 1.532 & 1.558 & 1.566 & 1.565 \\
\hline & $\begin{array}{c}\text { Period } 3 \text { (08:III- } \\
\text { 10:IV) }\end{array}$ & 1.730 & 1.831 & 1.902 & 1.947 & 1.963 & 1.968 \\
\hline \multirow{2}{*}{$\begin{array}{l}\text { Macro perfor- } \\
\text { mance change } \\
\qquad\left(\Delta \mathrm{P}^{\mathrm{j}}{ }_{\mathrm{j}+1} / \mathrm{P}_{\mathrm{j}}\right)\end{array}$} & $\begin{array}{l}\text { Period } 2 \text { - Peri- } \\
\quad \text { od } 1\end{array}$ & $18 \%$ & $24 \%$ & $29 \%$ & $33 \%$ & $35 \%$ & $37 \%$ \\
\hline & $\begin{array}{l}\text { Period } 3 \text { - Peri- } \\
\quad \text { od } 2\end{array}$ & $-117 \%$ & $-105 \%$ & $-92 \%$ & $-80 \%$ & $-73 \%$ & $-67 \%$ \\
\hline \multirow{2}{*}{$\begin{array}{c}\text { Policy contri- } \\
\text { bution to perf. } \\
\text { change } \\
\left(\mathrm{Q}_{\mathrm{j}+\mathrm{j}}^{\mathrm{j}}=\Delta \mathrm{E}_{\mathrm{j}+1}^{\mathrm{j}} /\left|\Delta \mathrm{P}_{\mathrm{j}+1}^{\mathrm{j}}\right|\right)\end{array}$} & $\begin{array}{l}\text { Period } 2 \text { - Peri- } \\
\quad \text { od } 1\end{array}$ & $45 \%$ & $30 \%$ & $20 \%$ & $13 \%$ & $10 \%$ & $13 \%$ \\
\hline & $\begin{array}{l}\text { Period } 3 \text { - Peri- } \\
\text { od } 2\end{array}$ & $-90 \%$ & $-86 \%$ & $-81 \%$ & $-74 \%$ & $-69 \%$ & $-64 \%$ \\
\hline
\end{tabular}

Source: Own elaboration based on data from Datastream.

Comparing the pre- and post-crisis periods in Sweden produces very large macro performance losses: over $100 \%$ for $\lambda \in\left[\frac{1}{2}, \frac{2}{3}\right]$, and closer to $67 \%-80 \%$ for the more realistic range of $\lambda \in[0.9,0.99]$. Finally, policy would be responsible of somewhere between $64 \%$ and $90 \%$ of the increased volatility, depending on the chosen value for $\lambda$, again (as in the case of the U.K.) leaving a relatively small share of the responsibility of the macroeconomic performance loss to the presence of larger shocks. 


\section{MACROECONOMIC PERFORMANCE UNDER THE EURO}

Let's now turn to the question of examining how macroeconomic performance for Sweden, and the U.K. would have changed, if these three countries would have joined the 3rd stage of the EMU. To answer this, it is necessary to model the dynamics that inflation and real economic activity would have followed if these three countries would have adopted the Euro on January 1999. In other words, to project alternative paths for inflation and GDP growth starting 1999, assuming that these countries had a fixed exchange rate with respect to the Euro, and that their respective central banks had set their interest rate equal to the ECB rate.

The particular counter-factual analysis conducted is based on a recursive bootstrap technique6. The following two assumptions are sufficient to apply the parametric recursive bootstrap: First, the estimated model for each country in equations (1) and (2) must be correctly specified. In the graphical analysis subsection, I have provided evidence about the validity of the model by running a series of specification tests. Second, the corresponding errors, $u_{y t}$ and $u_{\pi t}$, must be uncorrelated. This latter assumption is satisfied by the evidence of stationarity and lack of serial correlation in the estimated residuals.

For each country, the bootstrap sample of real GDP growth and inflation is obtained in a recursive fashion, using the resulting parameters from estimating equations (1) and (2), while replacing each country's central bank rate with the ECB interest rate, and assuming a fixed exchange rate with respect to the Euro. I take the first four initial values of both the real output gap and inflation as given, thus employing the respective original values for 1998:I-1998:IV. Finally, the error terms in each period for the generated paths of inflation and real growth are obtained by resampling with replacement from the matrix consisting of the estimated residuals from both equations of the structural model.

I iterate the above described process to obtain 1,000 bootstrap samples of "alternate economies". These replications allow me to generate 1,000 different values for the relevant measures of volatility (i.e., the standard deviations of both inflation and GDP growth) for the three economies of interest between 1999:I-2010:IV. Thereafter, choose the average value - out of the 1,000 replications - from the pair of volatility measures, and set it as the estimate of the performance point under the Euro.

For both Sweden and the U.K. the outcome of this exercise is quite clear: If these two countries had joined the EMU, the reduction in macroeconomic volatility would have not been as successful as it was under independent monetary policy. The gain in macroeconomic performance from adopting the Euro would have been lower by about $10-11 \%$ for Sweden, and roughly $7-8 \%$ in the case of the U.K., irrespective of the choice made for $\lambda$. Overall, these results suggest that Sweden and the U.K. have been better off stabilizing inflation and real growth fluctuations while conducting independent monetary policy, than they would have if they had decided to enter the 3rd stage of the Maastricht Agreement.

$6 \quad$ For a detailed discussion of the procedure see Li and Maddala (1996). 


\section{CONCLUSIONS}

In this paper I study the changes in macroeconomic volatility between the pre- and post-Euro periods for two countries who opted out of joining the EMU: Sweden and the U.K. I assess the role their respective independent monetary authorities have played in the stabilization process and then proceed to compare this outcome with a scenario in which these two countries would have adopted the Euro.

The two main observations that can be extracted from this analysis are: (i) monetary policy played a sizeable role in contributing to the reduction in inflation and real growth fluctuations, for both Sweden in the U.K. between 1991 and 1998, and 1999 and the second quarter of 2008; and (ii) none of these countries would have experienced a larger macroeconomic performance gain if they had joined the EMU in 1999.

As a final note, in the context of the U.K.'s decision to withdraw from the European Union (per the referendum of June 2016), one potential additional conclusion of this paper is that - in terms of output and inflation volatility - there would likely be no downside for the U.K. from not forming part of the EMU and the EU; provided of course that the British economy does not become more susceptible to shocks.

\section{ACKNOWLEDGEMENTS}

I would like to thank Claude Lopez, Glenn Rudebusch and Craig Burnside for useful discussion, and an anonymous referee and participants at the workshop "The First Decade of European Monetary Union" in Munster, Germany, for their comments. A substantial part of this research was conducted while I held the position of Senior Economist at Banque de France. However, the views expressed in this paper are my own, and do not necessarily reflect those of either Banque de France, or the Eurosystem.

\section{REFERENCES}

Ahmed, S., Levin, A., \& Wilson, B. A. (2002). Recent U.S. Macroeconomic Stability: Good Luck, Good Policies, or Good Practices? (International Financial Discussion Papers No. 730). Washington, DC.: Board of Governors of the Federal Reserve System.

Alesina, A., \& Barro, R. J. (2002). Currency Unions. The Quarterly Journal of Economics, 117(2), 409-436. https://doi.org/10.1162/003355302753650283

Bernanke, B. S., Laubach, T., Mishkin, F. S., \& Posen, A. S. (1999). Inflation Targeting: Lessons from the International Experience. Princeton, N.J.: Princeton University Press.

Cecchetti, S. G., Flores-Lagunes, A., \& Krause, S. (2006). Has Monetary Policy become more Efficient? a Cross-Country Analysis*. The Economic Journal, 116(511), 408-433. https://doi. org/10.1111/j.1468-0297.2006.01086.x

Chow, G. C. (1975). Analysis and control of dynamic economic systems. New York: John Wiley and Sons.

Clarida, R., Galí, J., \& Gertler, M. (1999). The Science of Monetary Policy: A New Keynesian Perspective. Journal of Economic Literature, 37(4), 1661-1707. https://doi.org/10.1257/jel.37.4.1661

Clarida, R., Galí, J., \& Gertler, M. (2000). Monetary Policy Rules and Macroeconomic Stability: Evidence and Some Theory. The Quarterly Journal of Economics, 115(1), 147-180. https://doi. org/10.1162/003355300554692

Cover, J. P., \& Pecorino, P. (2005). Price and Output Stability under Price-Level Targeting. Southern Economic Journal, 72(1), 152-166. 
Dynan, K. E., Elmendorf, D. W., \& Sichel, D. E. (2006). Can financial innovation help to explain the reduced volatility of economic activity? Journal of Monetary Economics, 53(1), 123-150. https://doi.org/10.1016/j.jmoneco.2005.10.012

Fuhrer, J. C. (1997). Inflation/Output Variance Trade-Offs and Optimal Monetary Policy. Journal of Money, Credit and Banking, 29(2), 214-234. https://doi.org/10.2307/2953676

Herrera, A. M., \& Pesavento, E. (2005). The Decline in U.S. Output Volatility. Journal of Business \& Economic Statistics, 23(4), 462-472. https://doi.org/10.1198/073500104000000596

Krause, S., \& Méndez, F. (2008). Institutions, arrangements and preferences for inflation stability: Evidence and lessons from a panel data analysis. Journal of Macroeconomics, 30(1), 282-307. https://doi.org/10.1016/j.jmacro.2006.11.001

Li, G. S. H., \& Maddala. (1996). Bootstrapping time series models. Econometric Reviews, 15(2), 115158. https://doi.org/10.1080/07474939608800344

McConnell, M. M., \& Perez-Quiros, G. (2000). Output Fluctuations in the United States: What Has Changed since the Early 1980's? American Economic Review, 90(5), 1464-1476. https://doi. org/10.1257/aer.90.5.1464

McMillin, W., \& Fackler, J. S. (2006). Estimating the Inflation-Output Variability Frontier with Inflation Targeting: A VAR Approach (Departmental Working Paper No. 2006-17). Department of Economics, Louisiana State University.

Mishkin, F., \& Schmidt-Hebbel, K. (2002). A Decade of Inflation Targeting in the World: What Do We Know and What Do We Need to Know? In N. Loayza \& R. Soto (Eds.), Inflation Targeting: Design, Performance, Challenges (pp. 171-219). Central Bank of Chile.

Pesaran, M. H., Smith, L. V., \& Smith, R. P. (2005). What if the UK had Joined the Euro in 1999? An Empirical Evaluation using a Global VAR (IEPR Working Paper No. 05.24). Institute of Economic Policy Research (IEPR).

Phillips, P. C. B., \& Perron, P. (1988). Testing for a unit root in time series regression. Biometrika, 75(2), 335-346. https://doi.org/10.1093/biomet/75.2.335

Rose, A. K., \& Engel, C. (2002). Currency Unions and International Integration. Journal of Money, Credit and Banking, 34(4), 1067-1089.

Rudebusch, G. D., \& Svensson, L. E. O. (1999). Policy Rules for Inflation Targeting. In J. B. Taylor (Ed.), Monetary Policy Rules (pp. 203-246). Chicago: University of Chicago Press.

Rudebusch, G. D., \& Svensson, L. E. O. (2000). Eurosystem Monetary Targeting: Lessons from US Data (CEPR Discussion Paper No. 2522). Centre for Economic Policy Research.

Söderström, U. (2008). Re-Evaluating Swedish Membership in EMU: Evidence from an Estimated Model (CEPR Discussion Paper No. 7062). CEPR. Discussion Papers. Retrieved from http:// www.cepr.org/active/publications/discussion_papers/dp.php?dpno=7062

Stock, J. H., \& Watson, M. W. (2002). Has the Business Cycle Changed and Why? NBER Macroeconomics Annual, 17, 159-218. https://doi.org/10.1086/ma.17.3585284

Stock, J. H., \& Watson, M. W. (2003). Has the Business Cycle Changed? Evidence and Explanations (Prepared for the Federal Reserve Bank of Kansas City symposium, "Monetary Policy and Uncertainty"). Jackson Hole, Wyoming, August 28-30, 2003.

Svensson, L. E. O. (1997). Inflation forecast targeting: Implementing and monitoring inflation targets. European Economic Review, 41(6), 1111-1146. https://doi.org/10.1016/S00142921(96)00055-4

Taylor, J. B. (1979). Estimation and Control of a Macroeconomic Model with Rational Expectations. Econometrica, 47(5), 1267-1286. https://doi.org/10.2307/1911962

Walsh, C. E. (1995). Recent Central-Bank Reforms and the Role of Price Stability as the Sole Objective of Monetary Policy. NBER Macroeconomics Annual, 10, 237-252. https://doi. org/10.1086/654278 


\section{APPENDIX}

\section{Diagnostics and Specification Analysis}

In this Appendix I detail several diagnostic and specification tests undertaken for the two-equation AD-AS model in (1) and (2); specifically, the time-series properties of the data and the characteristics of the estimated residuals.

A first test of model adequacy is to establish that the estimated residuals are uncorrelated. Autocorrelation would be evidence of misspecification. Using a Durbin-h test applied to the residuals of the two-equation model, there is no evidence to reject the null hypothesis of no autocorrelation at a $1 \%$ level or higher for both countries and subperiods. At a $5 \%$ level the only exceptions are equation (1) for Period 1 in the case of Sweden; and equation (2) for the U.K., also for Period 1. Upon further inspection of the residuals in these two cases, one can rule out any significant presence of autocorrelation.

Also, there is no statistical evidence suggesting autoregressive conditional heteroskedasticty in the equations for both countries and periods at the $1 \%$ significance level. At the $5 \%$ level, the only rejection is for the specification for the inflation equation for Period 2 and Period 3 in the case of the U.K. This suggests that, in general, residuals are spherical.

Finally, for the derivation of the efficiency frontier, described in the next section, and the application of the simulation method proposed in Section IV, it is necessary for the residuals to be stationary. This requires either that the endogenous variables be stationary themselves, or for some cointegrating relationship to be present among them. Since the distinction between these two is immaterial for the purposes of the analysis to be conducted on Section V, I perform a test for the non-stationarity of the estimated residuals. Using the Phillips-Perron (1988)"DOI":"10.1093/biomet/75.2.335",'ISSN":"0006-3444, 1464-3510","journalAbbreviation":"-

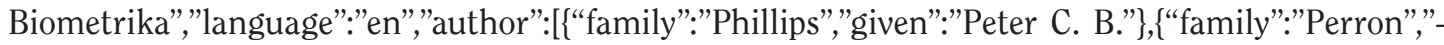
given":"Pierre"\}],"issued":[“date-parts":[[“1988”,1,6]]\}\},"suppress-author":true\}],"schema":"https:// github.com/citation-style-language/schema/raw/master/csl-citation.json"\} test leads to rejecting the null hypothesis of non-stationarity at the $1 \%$ significance level in all countries for both countries and periods. This provides strong support for the compatibility of the model specification with the integration properties of the data. 